\title{
Perkinsus mediterraneus n. sp., a protistan parasite of the European flat oyster Ostrea edulis from the Balearic Islands, Mediterranean Sea
}

\author{
Sandra M. Casas ${ }^{1}$, Amalia Grau ${ }^{2}$, Kimberly S. Reece ${ }^{3}$, Kathleen Apakupakul ${ }^{3}$, \\ Carlos Azevedo ${ }^{4}$, Antonio Villalba ${ }^{1, *}$ \\ ${ }^{1}$ Centro de Investigacións Mariñas, Consellería de Pesca e Asuntos Marítimos, Xunta de Galicia, Apartado 13, \\ 36620 Vilanova de Arousa, Spain \\ ${ }^{2}$ Estación de Acuicultura, D. G. Pesca, Govern Balear, Port d'Andratx, Mallorca, 07158 Spain \\ ${ }^{3}$ School of Marine Science, Virginia Institute of Marine Science, College of William and Mary, Gloucester Point, \\ Virginia 23062, USA \\ ${ }^{4}$ Department of Cellular Biology, Institute of Biomedical Sciences, University of Oporto, Porto 4099-003, Portugal
}

\begin{abstract}
A new species, Perkinsus mediterraneus, a protistan parasite of the European oyster Ostrea edulis (L.), farmed along the coast of the Balearic Islands, Mediterranean Sea, is described. Morphological examinations with light and transmission electron microscopy, DNA sequenceanalysis and enlargement in Ray's fluid thioglycollate medium (RFTM) confirmed that this parasite belongs to the genus Perkinsus. Specific morphological and genetic characteristics indicated that it should be considered a new species in the genus. Sequencing of the small subunit ribosomal (ssu rRNA) gene confirmed that the parasite belongs to the genus Perkinsus, and sequences of the internal transcribed spacer (ITS) were distinct from any Perkinsus ITS sequences previously published and/or deposited in the GenBank. Phylogenetic analysis revealed that the ITS sequences of the new species formed a monophyletic group comprising a sister clade to the $P$. atlanticus/olseni group. In addition, morphological differences were observed between the new species and the other described Perkinsus spp.. After incubation in RFTM for $1 \mathrm{wk}$, the prezoosporangium had reached an extremely large size $(97.4 \pm 1.99 \mu \mathrm{m})$ (mean $\pm \mathrm{SE}$ ), and after $2 \mathrm{wk}$ incubation had again almost doubled in size $(167.1 \pm 8.09 \mu \mathrm{m})$. The discharge-tube length was one sixth the diameter of the zoosporangium, i.e. a ratio of 17.36:97.38, the lowest ratio observed for any Perkinsus species. At the ultrastructural level, zoosporangia and zoospores exhibited some differences compared to other Perkinsus species.
\end{abstract}

KEY WORDS: Perkinsus mediterraneus n. sp. - Ostrea edulis · Oyster parasite - Ultrastructure · Zoosporulation · ssu rRNA gene $\cdot$ Internal transcribed spacer $\cdot$ Perkinsus atlanticus

\section{INTRODUCTION}

Perkinsus spp. comprise a well-known group of molluscan parasites. Perkinsosis has been associated with elevated mortalities of commercially important molluscs in the Gulf of Mexico, along the Atlantic coast of North America (Andrews \& Hewatt 1957, Mackin \& Hopkins 1962, Burreson \& Ragone Calvo 1996, Ford 1996, Soniat 1996), in British Columbia (Bower et al. 1998), along the Atlantic coast of SW Europe (Azevedo
1989), in the Mediterranean Sea (da Ros \& Canzonier 1985, Santmartí et al. 1995) in southern Australia (Lester \& Davis 1981, Goggin \& Lester 1995) and along the south and west coasts of Korea (Choi \& Park 1997, Park \& Choi 2001). Taxonomic placement of the genus Perkinsus is controversial. Several genetic (Fong et al. 1993, Goggin \& Barker 1993, Siddall et al. 1995, 1997, Flores et al. 1996, Reece et al. 1997, Kotob et al. 1999, de la Herrán et al. 2000, Murrell et al. 2002) and morphological (Siddall et al. 1997) studies have suggested 
that Perkinsus species are dinoflagellates, or are closely related to them. Other studies have placed the genus Perkinsus within the alveolates, in a new phylum Perkinsozoa, together with the phyla Dinoflagellata, Apicomplexa and Ciliophora (Norén et al. 1999).

To date, the genus Perkinsus has comprised 6 species: P. marinus in the eastern oyster Crassostrea virginica (Mackin et al. 1950) along the Atlantic and Gulf coasts of the USA, P. olseni in the blacklip abalone Haliotis ruber from Australia (Lester \& Davis 1981), P. atlanticus (Azevedo 1989) in the carpet-shell clam Tapes decussatus from the Iberian Peninsula, P. qugwadi in the Japanese scallop Patinopecten yessoensis (Blackbourn et al. 1998) from British Columbia, Canada, Perkinsus chesapeaki (McLaughlin et al. 2000) in the softshell clam Mya arenaria from Chesapeake Bay, USA, and $P$. andrewsi (Coss et al. 2001b) in Macoma balthica from Delaware Bay.

In European waters, Perkinsus-like organisms were detected in the clam Tapes decussatus and the flat oyster Ostrea edulis in 1978 (da Ros \& Canzonier 1985). P. atlanticus is the only species of the genus identified along the European coasts to date. It has been found in T. decussatus from the Iberian Peninsula: Algarve, South Portugal (Azevedo 1989), Huelva, South Spain (de la Herrán et al. 2000) and Galicia, NW Spain (Robledo et al. 2000, Casas et al. 2002a) and in T. philippinarum from Cataluña (NE Spain) (Sagristà et al. 1996).

The occurrence of Perkinsus-like organisms in the Mediterranean Sea has been documented in Ostrea edulis, Crassostrea gigas, Tapes decussatus, T. philippinarum, Venerupis aurea, Venus verrucosa, Callista chione, Cerastoderma edule, Mytilus galloprovincialis, Chamelea gallina and Musculista senhousia from Italian coastal waters (da Ros \& Canzonier 1985, Ceschia et al. 1991, Berilli et al. 1998, Canestri-Trotti et al. 1999, 2000a,b), and in bivalves from the French Mediterranean coasts (Goggin 1992), but none of those studies identified the parasite to species level.

Cases of infection by Perkinsus-like organisms were observed in the tissues of the European flat oyster Ostrea edulis cultivated in the Balearic Islands, Mediterranean Sea. This article describes the morphological characteristics of different life stages and DNA sequences of the rRNA complex of the oyster parasite from Balearic Islands, and identifies a new species of the genus Perkinsus, $P$. mediterraneus n. sp.

\section{MATERIALS AND METHODS}

Oyster sampling. European flat oysters infected by a Perkinsus-like organism were found during an histological survey of a commercial oyster-growing site in close proximity to Maó Port (Isle of Menorca, Balearic Islands, Spain), in the western Mediterranean Sea. The survey involved monthly harvesting of oyster samples, which were processed by standard histological techniques. Briefly, an approximately $5 \mathrm{~mm}$ thick section of tissue containing gills, visceral mass, and mantle lobes was excised, fixed in Davidson's solution (Shaw \& Battle 1957) and embedded in paraffin. Sections of $5 \mu \mathrm{m}$ thickness were stained with Harris-hematoxylin and eosin. Histological sections of infected oysters were examined by light microscopy to determine the morphology of the Perkinsus-like organism.

Isolation of prezoosporangia and induction of zoosporulation. A preliminary trial was performed in November 1998. The digestive gland, gills and rectum of 25 oysters collected from the same site were incubated in Ray's fluid thioglycollate medium (RFTM) (Ray 1966) to induce transformation of trophozoites of the Perkinsus-like parasite into prezoosporangia. After $1 \mathrm{wk}$ in RFTM at room temperature in the dark, the tissues were homogenised (8000 $1 \mathrm{~min}^{-1}, 30 \mathrm{~s}$, ultraturrax T-25, IKA Labortechnik), and the prezoosporangia were isolated (de la Herrán et al. 2000, Casas et al. 2002a) as follows: oyster tissues were trypsinised $(0.25 \%)$ for 60 to $90 \mathrm{~min}$, and prezoosporangia were separated by passing the suspension through sieves of $425,225,140$ and $30 \mu \mathrm{m}$. Only material retained on the $30 \mu \mathrm{m}$ sieve was processed further, since no significant numbers of prezoosporangia were detected in the other sieve sizes. Prezoosporangia in the $30 \mu \mathrm{m}$ sieve were washed with sterile filtered $(0.22 \mu \mathrm{m})$ seawater (35\%) plus antibiotics (200 $\mathrm{U} \mathrm{ml}^{-1}$ Penicillin G and $400 \mu \mathrm{g} \mathrm{ml}^{-1}$ streptomycin) (SFSWA). Prezoosporangia were incubated at $22^{\circ} \mathrm{C}$ in the dark in Petri plates with SFSWA to induce zoosporulation. Plates were checked daily by light microscopy to monitor cell morphology until zoosporulation.

A second trial was performed in November 1999. The digestive gland, gills and rectum of 30 oysters were incubated for a longer period ( $2 \mathrm{wk}$ ) in RFTM at room temperature. The incubated tissues were homogenised and trypsinised as described above. Because of the increased size of prezoosporangia after extended incubation, only the 425 and $30 \mu \mathrm{m}$ sieves were used to avoid loss of prezoosporangia in discarded 225 and $140 \mu \mathrm{m}$ sieve material. Prezoosporangia retained in the $30 \mu \mathrm{m}$ sieve were processed as described above to induce zoosporulation.

Transmission electron microscopy. Zoosporangia and zoospores obtained in the second trial were washed and centrifuged. The pellets were fixed in $2.5 \%$ glutaraldehyde in $0.2 \mathrm{M}$ sodium cacodylate buffer, $\mathrm{pH} 7.2$, for $2 \mathrm{~h}$ at $4^{\circ} \mathrm{C}$. The pellets were then washed twice with the same buffer, and postfixed in buffered $2 \% \mathrm{OsO}_{4}$ for $2 \mathrm{~h}$ at $4^{\circ} \mathrm{C}$. The cells were 
immersed in $1.5 \%$ agar solution, and the agar blocks were dehydrated in an ethanol series and embedded in Epon. Ultrathin sections were double-stained with uranyl acetate and lead citrate, and observed in a JEOL 1010 transmission electron microscope (TEM) operated at $60 \mathrm{kV}$.

DNA-sequencing. Genomic DNA isolation: Zoosporangia and zoospores obtained from infected oysters $(\mathrm{N}=20)$ in the second trial were washed and centrifuged. Pellets were covered with tissue-storage buffer $(0.25 \mathrm{M}$ ethylenediamine tetraacetate [EDTA], $20 \%$ dimethylsulfoxide [DMSO], saturated $\mathrm{NaCl}[\mathrm{pH}$ 8.0]) (Seutin et al. 1991) and shipped to the Virginia Institute of Marine Science for further processing. Before DNA extraction, the zoosporangia and zoospores were again pelleted, and washed with phosphate-buffered saline. DNA was extracted using a CTAB (1\% N-cetyl,N,N,N-trimethylammonium bromide)-based DNA extraction method (Carlini \& Graves 1999) with twice the published concentration of proteinase- $\mathrm{K}$ in the lysis buffer.

PCR amplification: The small subunit ribosomal RNA (ssu rRNA) gene and the internal transcribed spacer region (ITS) of the ribosomal RNA gene unit were amplified in the polymerase chain reaction from the genomic DNA. Amplification of the ssu rRNA gene required a Perkinsus-specific primer that annealed within the ITS region that was paired with a 'universal' ssu primer (16S-A, Medlin et al. 1988). The Perkinsusspecific ITS primer, 'PerkITS320comp' (5'-CCTTTGTGCAGTWTGCGTTG-3') was designed to be used in conjunction with $16 \mathrm{~S}-\mathrm{A}$ and to preferentially amplify an approximately $2100 \mathrm{bp}$ fragment of parasite DNA containing the ssu gene and a portion of the ITS region (ssu/ITS) while avoiding amplification of host and other contaminating DNAs. Amplifications were performed with 10 to $50 \mathrm{ng}$ of genomic DNA in $25 \mu \mathrm{l}$ reactions, using the reaction conditions recommended for the BRL PCR Reagent System (Life Technologies) with the addition of $20 \%$ BSA (bovine serum albumin; $1 \mathrm{mg}$ $\mathrm{ml}^{-1}$ ). Cycling parameters for the ssu rRNA gene/ ITS region were as follows: an initial denaturation of $4 \mathrm{~min}$ at $94^{\circ} \mathrm{C}$ followed by 35 cycles $\left(30 \mathrm{~s}\right.$ at $94^{\circ} \mathrm{C}, 30 \mathrm{~s}$ at $53^{\circ} \mathrm{C}$, and $2 \mathrm{~min}$ at $68^{\circ} \mathrm{C}$ ) and a final extension of $5 \mathrm{~min}$ at $68^{\circ} \mathrm{C}$.

A previously designed Perkinsus-specific ITS region primer pair (D) (Casas et al. 2002a) was used in this study to amplify approximately $700 \mathrm{bp}$ of the ITS region. Amplification conditions and parameters were as previously described (Casas et al. 2002a). ssu/ITS and ITS amplification products were cloned and sequenced as previously described (Casas et al. 2002a), except that, in order to determine the complete sequence of the ssu/ITS fragments, 2 internal sequencing primers were designed based on Perkinsus DNA sequences. The nested internal sequencing primers, PerkspSeqF, 5'GCTCGTAGTTGGATTTCTGC-3' and PerkspSeqR, 5'CAAAAGATTACCCTAACCCTACCG-3', were used in conjunction with the M13F and M13R primers to allow complete concatenation of the sequences. All cloned sequences were subjected to BLAST (basic local alignment search tool) searches (Altschul et al. 1990) of the National Center for Biotechnology Information (NCBI) GenBank database to help distinguish Ostrea edulis Perkinsus sp. sequences from host or other contaminant sequences.

Phylogenetic analysis: ssu sequences obtained from the Ostrea edulis Perkinsus sp. were aligned to available Perkinsus spp. ssu sequences (Fong et al. 1993, GenBank Accession No. X75762; Goggin \& Barker 1993, Accession No. L07375; S. I. Kotob et al. unpubl., Accession Nos. AF042708 and AF042707; Robledo et al. 2000, Accession No. AF140295; C. A. Coss et al. unpubl., Accession No. AF252288; Coss et al. 2001b, Accession No. AF102171), and to those of 2 Perkinsus host species, Crassostrea virginica (Littlewood et al. 1991, Accession No. X60315) and Tapes decussatus (B. Novoa \& A. J. Figueras unpubl., Accession No. AF295121) using the CLUSTAL-W algorithm (Thompson et al. 1994) in the MacVector 7.0 DNA Sequence Analysis Software package (Oxford Molecular). Using the same method, ITS sequences obtained in this study were aligned to those of other Perkinsus spp. (Goggin 1994, Accession Nos. PAU07697, PMU07700, POU07701, PSU07698, PSU07699; S. I. Kotob et al. unpubl., Accession Nos. AF091541, AF091542, AF126022, AF150988, AF150989, AF150990; G. D. Brown et al. unpubl., ACcession Nos. AF149876, AF150985, AF150986, AF150987; Robledo et al. 2000, Accession No. AF140295; Coss et al. 2001b, Accession Nos. AF252288, AF102171; D. Hervio et al. unpubl., Accession No. AF151528; Casas et al. 2002a, Accession Nos. AF369967 to AF369979; Dungan et al. 2002, Accession Nos. AF440464 to AF440471; Casas et al. 2002b, Accession Nos. AF441207 to AF441218). Parsimony jackknife analysis of each set of sequences was performed using PAUP* 4b8.0 (Swofford 2001) with 100 resamplings of 100 random-addition replicates.

Influence of length of incubation in RFTM on size of Perkinsus atlanticus prezoosporangium. An experiment was performed to test the influence of length of incubation in RFTM on Perkinsus atlanticus prezoosporangium size, in order to evaluate the taxonomic significance of the large size of the Perkinsus-like prezoosporangia isolated from the oysters. $P$. atlanticus was chosen because it is the only species of the genus described from European waters thus far. Carpet-shell clams Tapes decussatus (> $40 \mathrm{~mm}$ ) were collected from an intertidal bed infected by $P$. atlanticus, located in Vilalonga (Ría de Arousa, Galicia, NW Spain). We 
selected 27 clams with the highest numbers of whitish pustules on their gill surfaces (a conspicuous sign of infection by $P$. atlanticus) for $P$. atlanticus isolation, and divided them into 3 groups (A, B and C) of 9 clams each. Gills of the 9 clams in Group A were cut into small fragments, one-third of which was incubated in RFTM for $7 \mathrm{~d}$ (Replicate 7A), another third was incubated in RFTM for $14 \mathrm{~d}$ (Replicate 14A), and the remaining one-third was incubated in RFTM for $21 \mathrm{~d}$ (Replicate 21A). The gills of clams in Groups B and C were processed similarly. Thus, 3 replicates $(A, B$, and C) were performed for each of the 3 incubation periods (7, 14 and $21 \mathrm{~d})$.

After incubation, gill fragments of each replicate were separately trypsinised $(0.25 \%)$ for $1 \mathrm{~h}$, a $1 \mathrm{ml}$ sample was taken from each replicate, the diameter of 50 cells was measured, and cellular viability was determined with neutral red $\left(10 \mathrm{mg} \mathrm{l}^{-1}\right)$.

Statistical analysis. Differences in Perkinsus atlanticus prezoosporangium size among the 3 incubation periods were compared by 1-way ANOVA followed by a Fisher test, using MINITAB 13 software.

\section{RESULTS}

\section{Morphology of parasitic stages in oyster tissues}

Different stages corresponding to the life cycle of a Perkinsus-like parasite were observed in histological sections of Ostrea edulis (Figs. 1 to 4). Trophozoites occurred mostly in the connective tissue of different organs (visceral mass, gills, labial palps, mantle lobes) and also inside gonad follicles invaded by haemocytes. Trophozoites were spherical cells (mean diameter \pm SE $=7.9 \pm 0.34 \mu \mathrm{m} ; \mathrm{N}=50$; range $=4$ to $19 \mu \mathrm{m})$, each containing a large vacuole that occupied most of the cell volume, conferring a 'signet ring' appearance to the cell (Figs. 1 \& 2). A vacuoplast was evident within the vacuole (Fig. 2). The nucleus was located in the periphery of the cell, and sometimes contained a nucleolus (Figs. 1 \& 2). The cell was surrounded by a wall-like structure (Figs. 1 \& 2). Multicellular stages, indicating vegetative multiplication of a mother cell, were also observed, with daughter cells in a rosette-like arrangement inside the wall-like structure of the mother cell (Figs. 3 \& 4).

Only light-to-moderate infections were visible in the histological sections. The infection evoked haemocytic infiltration of the connective tissue in the proximity of the parasite (Figs. 1 to 4). Trophozoites were frequently observed in the cytoplasm of haemocytes and, less frequently, free in the connective tissue or surrounded by a few haemocytes. Partially degraded trophozoites were visible both inside and outside the haemocytes.

\section{Cellular morphology during zoosporulation}

Under light microscopy, prezoosporangia of the Perkinsus-like parasite isolated from Ostrea edulis in the first trial appeared spherical, with a large vacuole that displaced the nucleus to the periphery of the cell (Fig. 5). The mean diameter $( \pm \mathrm{SE})$ of the prezoosporangia was $97.4 \pm 1.99 \mu \mathrm{m}(\mathrm{N}=53$, range $=62$ to $135 \mu \mathrm{m})$. Zoosporulation occurred in prezoosporangia incubated in seawater (Figs. 6 to 8). It began with the formation of a discharge tube, progressing through successive karyokinesis and cytokinesis of the cell, and producing hundreds of zoospores. The mean length of the discharge tube was one-sixth $(17.36: 97.38 \mu \mathrm{m})$ the diameter of the zoosporangial body. Zoosporangia with 2 discharge tubes were not observed. Biflagellated zoospores were liberated through the discharge tube (Fig. 8) 5 to $6 \mathrm{~d}$ after transferring the prezoosporangia into seawater. Mean $( \pm \mathrm{SE})$ zoospore length was $4.4 \pm$ $0.18 \mu \mathrm{m}(\mathrm{N}=50$, range $=2.9$ to $5.8 \mu \mathrm{m})$.

The mean diameter of prezoosporangia of the Perkinsus-like parasite isolated from Ostrea edulis in the second trial was $167.1 \pm 8.09 \mu \mathrm{m}(\mathrm{N}=24$, range $=$ 110 to $317 \mu \mathrm{m})$. In addition to its larger size, the cell wall was thicker than in the first trial, and $4 \%(\mathrm{~N}=250)$ of the zoosporangia had 2 discharge tubes (Figs. 9 \& 10) instead of a single tube. The distance between the 2 tubes was variable and both tubes were similar in length. As in the first trial, zoosporulation progressed through successive karyokinesis and cytokinesis, and produced hundreds of zoospores that were liberated 5 to $6 \mathrm{~d}$ after transfer of the prezoosporangia into seawater.

Ultrastructural aspects of the zoosporulation sequence and zoospore morphology are shown in Figs. 11 to 17. In the first stages of zoosporulation, zoosporangia contained few and large prezoospores (Fig. 11). Prezoospore cytoplasm had numerous vacuoles, vacuoplasts, mitochondria and lipid droplets (Fig. 11). A vacuoplast was frequently visible in the vacuoles of prezoospores and zoospores (Figs. 11 to 17). Asynchrony was observed in the zoosporulation process, with large prezoospores that had not completed the division process and mature zoospores occurring simultaneously in zoosporangia (Fig. 12). Zoosporangia had a thick cell wall (9 to $10 \mu \mathrm{m}$ ), with 2 layers. The outer layer had an external glycocalyx-like structure and 2 thin, parallel, electron-dense layers (Fig. 13), the inner layer being the more electrondense (Fig. 14). Zoosporangia plugs and discharge tubes were formed from the inner layer of the wall (Fig. 14). Lomosomes were not observed in the zoosporangia wall.

Zoospores were uninucleated and biflagellated cells (Figs. 15 to 17). Zoospore shape was ellipsoidal to 


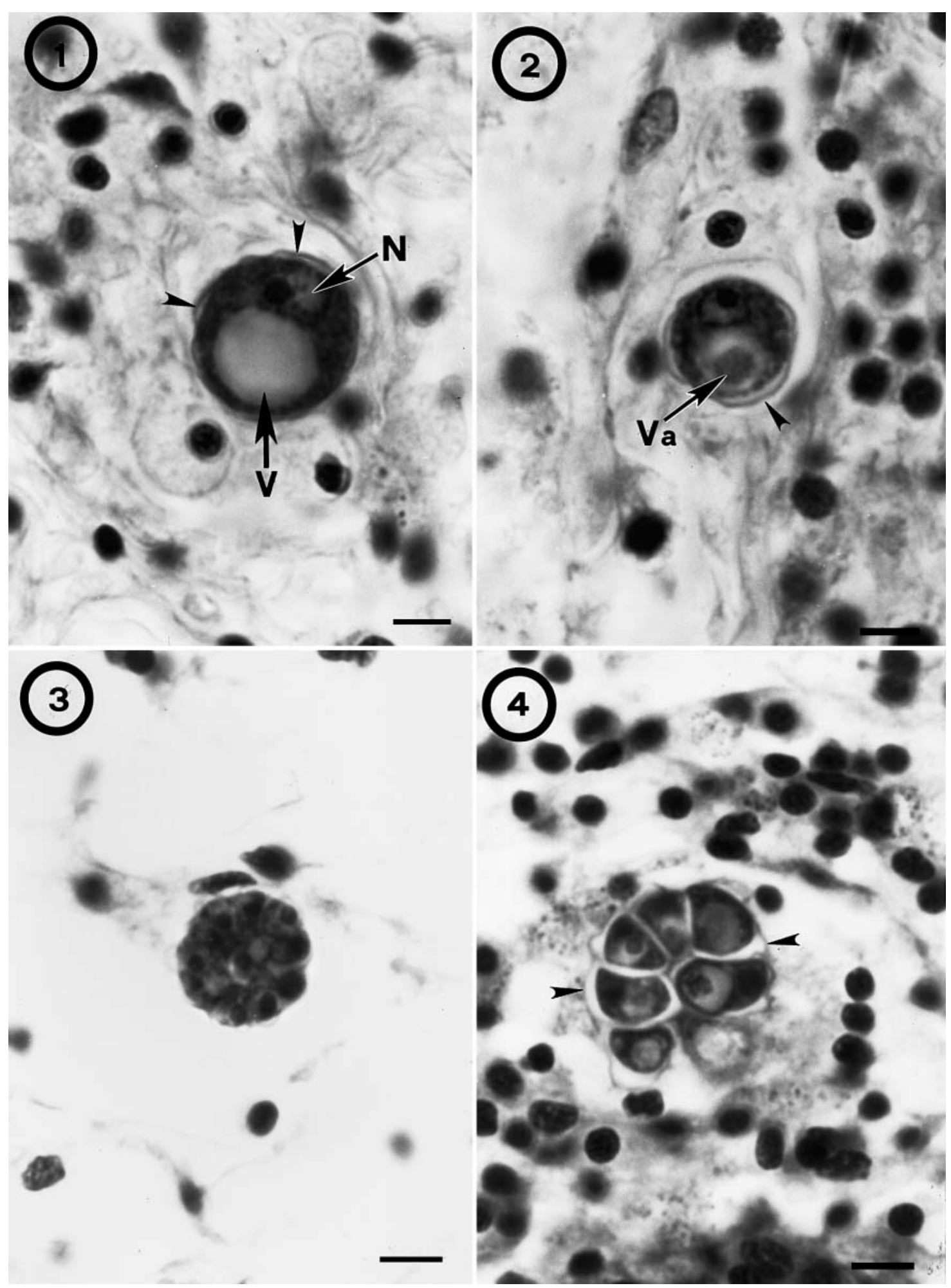

Figs. 1 to 4. Light micrographs of oyster Ostrea edulis tissues infected by Perkinsus mediterraneus n. sp. Fig. 1. Trophozoite covered by wall-like structure (arrowheads) in connective tissue of oyster visceral mass (N: nucleus; V: vacuole. Fig. 2. Trophozoite in area of oyster connective tissue infiltrated by haemocytes, showing parasite surrounded by wall-like structure (arrowhead) and vacuoplast (Va) inside large vacuole. Fig. 3. Multicellular stage resulting from vegetative multiplication of a mother cell with daughter cells in a rosette-like arrangement inside wall-like structure covering mother cell. Fig. 4. Later stage of vegetative multiplication, with individual daughter cells inside structure covering mother cell (arrowheads). All scale bars $=5 \mu \mathrm{m}$ 

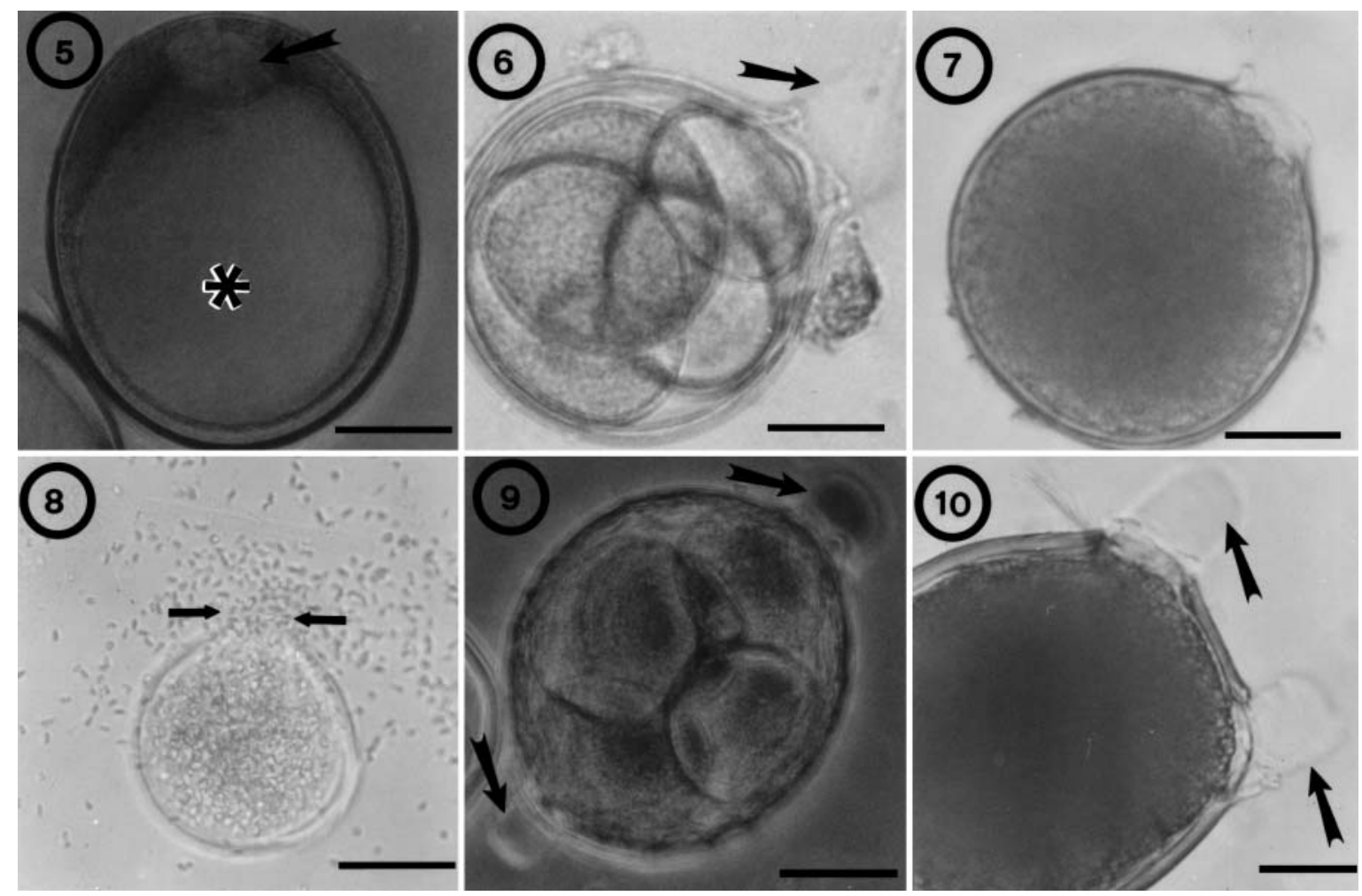

Figs. 5 to 10. Perkinsus mediterraneus n.sp. Bright-field micrographs showing progression of zoosporulation. Fig. 5. Prezoosporangium with large central vacuole $(*)$ and peripheral nucleus (arrow) (scale bar $=50 \mu \mathrm{m}$ ). Fig. 6. Zoosporangium with 4 prezoospores and discharge tube (arrow) (scale bar $=25 \mu \mathrm{m}$ ). Fig. 7. Zoosporangium containing hundreds of motile zoospores (scale bar $=25 \mu \mathrm{m}$ ). Fig. 8. Zoospores leaving zoosporangium through discharge tube (arrows) (scale bar $=50 \mu \mathrm{m})$. Fig. 9. Zoosporangium with 2 discharge tubes (arrows) at opposite ends of cell (scale bar $=50 \mu \mathrm{m})$. Fig. 10. Zoosporangium with 2 discharge tubes (arrows) in close proximity to each other (scale bar $\overline{=30 \mu \mathrm{m}}$ )

ovoid, with tapered anterior and rounded posterior ends. Both flagella were inserted laterally in the anterior part of the cell (Fig. 15) and had the typical eukaryotic microtubular arrangement of 9 doublets +2 . There was an electron-dense body inside the basal bodies (Fig. 15). A large nucleus was located in the posterior part of the cell, with the chromatin condensed at the periphery and lacking a patent nucleolus (Figs. 16 \& 17). The mitochondria (or mitochondrion) extended from the apical to the posterior part of the cell in a lateral position (Figs. $16 \& 17$ ). Mitochondria were of a bar-like shape, with tubular cristae in the periphery and a wide matrix (Fig. 17). Several vacuoles were scattered throughout the cytoplasm. Other zoospore structures described in Perkinsus spp. also were found. The apical ribbon was open-sided and located in the apical part of the cell (Fig. 17). The ribbon-associated vesicles were moderately electron-dense vesicular structures deployed in bundles with a wavy appearance (Figs. 16 \& 17). The ribbon-associated vesicles extended from the apical ribbon to the posterior region of the zoospores, wrapped around the nucleus, and then extended anteriorly. Toxicysts comprised a bundle of vesicular structures that extended from the apical ribbon to the posterior portion of the cell, maintaining a straight appearance and ending in a knob-like structure (Figs. 15 to 17 ). The rhoptries were vaseshaped electron-dense structures, and extended from the apical ribbon area to the posterior portion of the zoospores (Figs. 15 to 17). Cortical alveoli were observed in the anterior part of the zoospore surface (Fig. 17).

\section{DNA-sequencing}

A total of 9 ssu/ITS and 10 ITS DNA clones were sequenced. BLAST searches demonstrated that all the sequences obtained by PCR amplification with both 16S-A and PerkITS320comp and the Perkinsusspecific 'D' ITS primers most closely matched Perkinsus sequences in GenBank. The closest matches were to the $P$. atlanticus and $P$. olseni sequences. The sequence of the ITS portion of the ssu/ITS amplifica- 


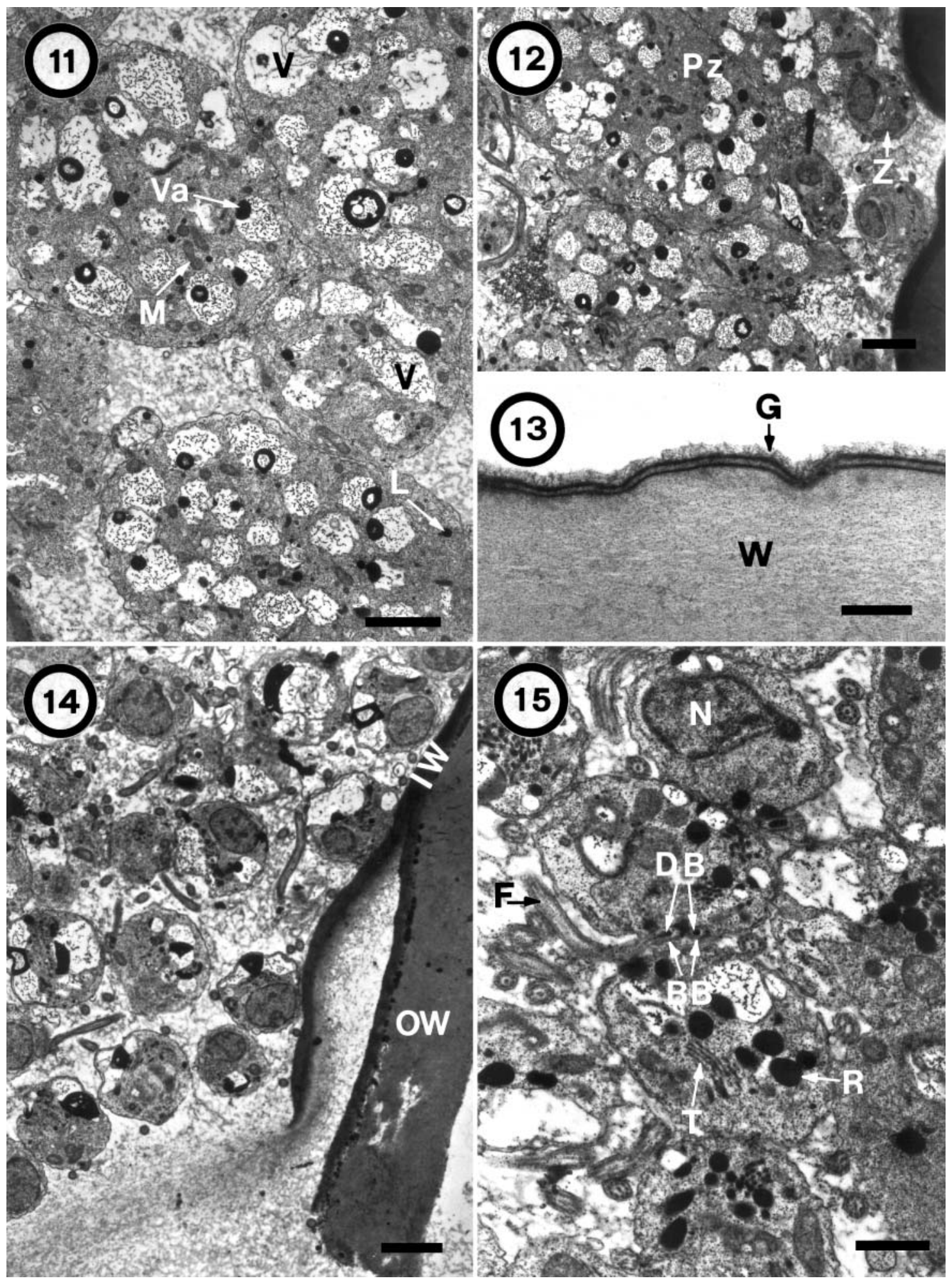

Figs. 11 to 15. Perkinsus mediterraneus n.sp. Transmission electron micrographs showing zoosporulation process. Fig. 11. Zoosporangium in early stage of zoosporulation containing large prezoospores with mitochondria (M), lipid droplets (L) and numerous vacuoles $(\mathrm{V})$ and vacuoplasts $(\mathrm{Va})(\mathrm{scale}$ bar $=2 \mu \mathrm{m})$. Fig. 12. Co-occurrence of prezoospores (Pz) and zoospores $(\mathrm{Z})$ inside a zoosporangium, denoting asynchronous divison (scale bar $=2 \mu \mathrm{m}$ ). Fig. 13. Enlargement of zoosporangium wall (W), showing outer layer and glycocalix-like structure $(\mathrm{G})($ scale bar $=0.5 \mu \mathrm{m})$. Fig. 14. Enlargement of discharge-pore area of zoosporangium, showing a plug blocking the pore; wall is divided into outer layer (OW) and electron-dense inner layer (IW); zoospores are visible inside zoosporangium (scale bar $=2 \mu \mathrm{m}$ ). Fig. 15. Zoospores inside zoosporangium showing nucleus (N), flagella (F), basal bodies (BB) and other zoospore structures (DB: electron-dense body; R: rhoptry; $\mathrm{T}$ : toxicyst) $(\mathrm{scale}$ bar $=1 \mu \mathrm{m})$ 


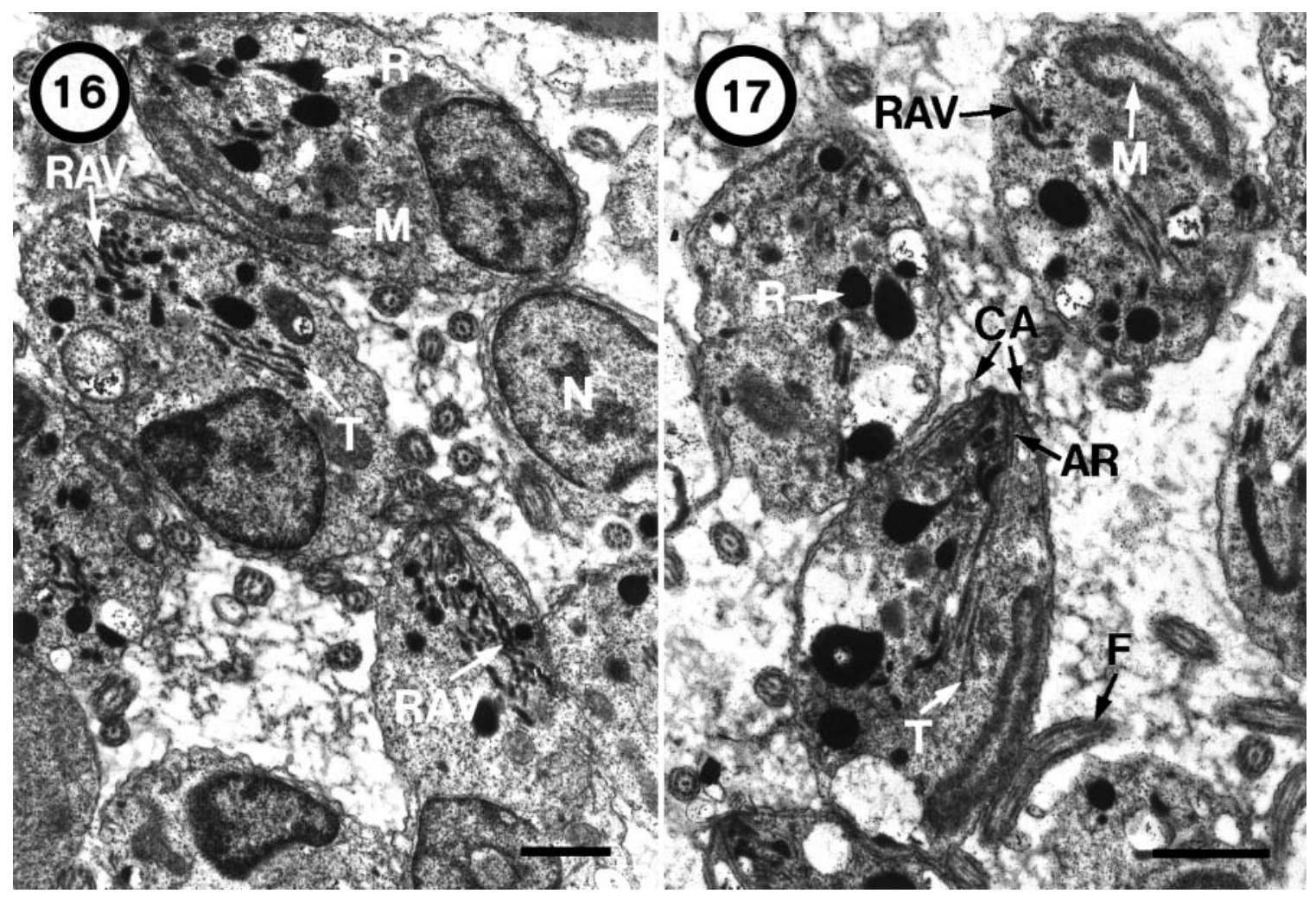

Figs. 16 \& 17. Perkinsus mediterraneus n. sp. Transmission electron micrographs of zoospores. Fig. 16. Zoospores with nucleus $(\mathrm{N})$, large mitochondrion (M), and some components of apical complex (R: rhoptry; RAV: ribbon-associated vesicle; T: toxicyst). Fig. 17. Zoospores showing other details of apical complex (AR: apical ribbon; CA: cortical alveolus; F: flagellum; M: mitochondrion; R: rhoptry; RAV: ribbon-associated vesicle; T: toxicyst). Both scale bars $=1 \mu \mathrm{m}$

tion product matched the ITS sequences obtained in the 'D' primer amplifications.

We found 10 polymorphic sites within the $1786 \mathrm{bp}$ ssu rRNA gene fragment among the DNA clones for the Ostrea edulis Perkinsus species. Among the ssu sequences available for all Perkinsus species, only 26 sites were parsimony-informative. Parsimony jackknife analysis of the ssu rRNA gene resulted in a tree (Fig. 18) that clearly separated the Crassostrea virginica and Tapes decussatus sequences from Perkinsus spp. sequences. ssu sequences from the $O$. edulis Perkinsus sp. did not group with host sequences, but with those of Perkinsus spp. with $100 \%$ jackknife support, indicating that the parasite DNA was targeted for amplification. There was relatively poor resolution, however, among Perkinsus ssu sequences. The Perkinsus sp. from Mercenaria mercenaria grouped with $P$. chesapeaki and $P$. andrewsi with $90 \%$ jackknife support. The Perkinsus sp. from Mya arenaria and P. marinus grouped together with $96 \%$ jackknife support. The Perkinsus sp. from Anadara trapezia, P. atlanticus and the O. edulis Perkinsus sp. were unresolved by the ssu analysis.
There were 12 polymorphic sites among the 10 DNA clones for the 643 bp ITS region fragment obtained for the Ostrea edulis Perkinsus sp.; 144 sites were parsimony-informative for the phylogenetic analysis based on Perkinsus spp. ITS sequences. All the $O$. edulis Perkinsus sp. ITS sequences formed a monophyletic group with $100 \%$ jackknife support (Fig. 19) comprising a sister group to a clade containing ITS region sequences from $P$. atlanticus, $P$. olseni, and Perkinsus sp. from Anadara trapezia and Perkinsus sp. from Chama pacificus. P. marinus sequences formed a monophyletic group with $100 \%$ jackknife support that comprised a sister group to the larger clade containing the $P$. atlanticus/ $P$. olseni and the $O$. edulis Perkinsus sp. sequences.

\section{Influence of RFTM incubation period on Perkinsus atlanticus prezoosporangium size}

The size increases of Perkinsus atlanticus cells in RFTM and prezoosporangium viability are shown in Table 1. Prezoosporangium size after $7 \mathrm{~d}$ incubation 


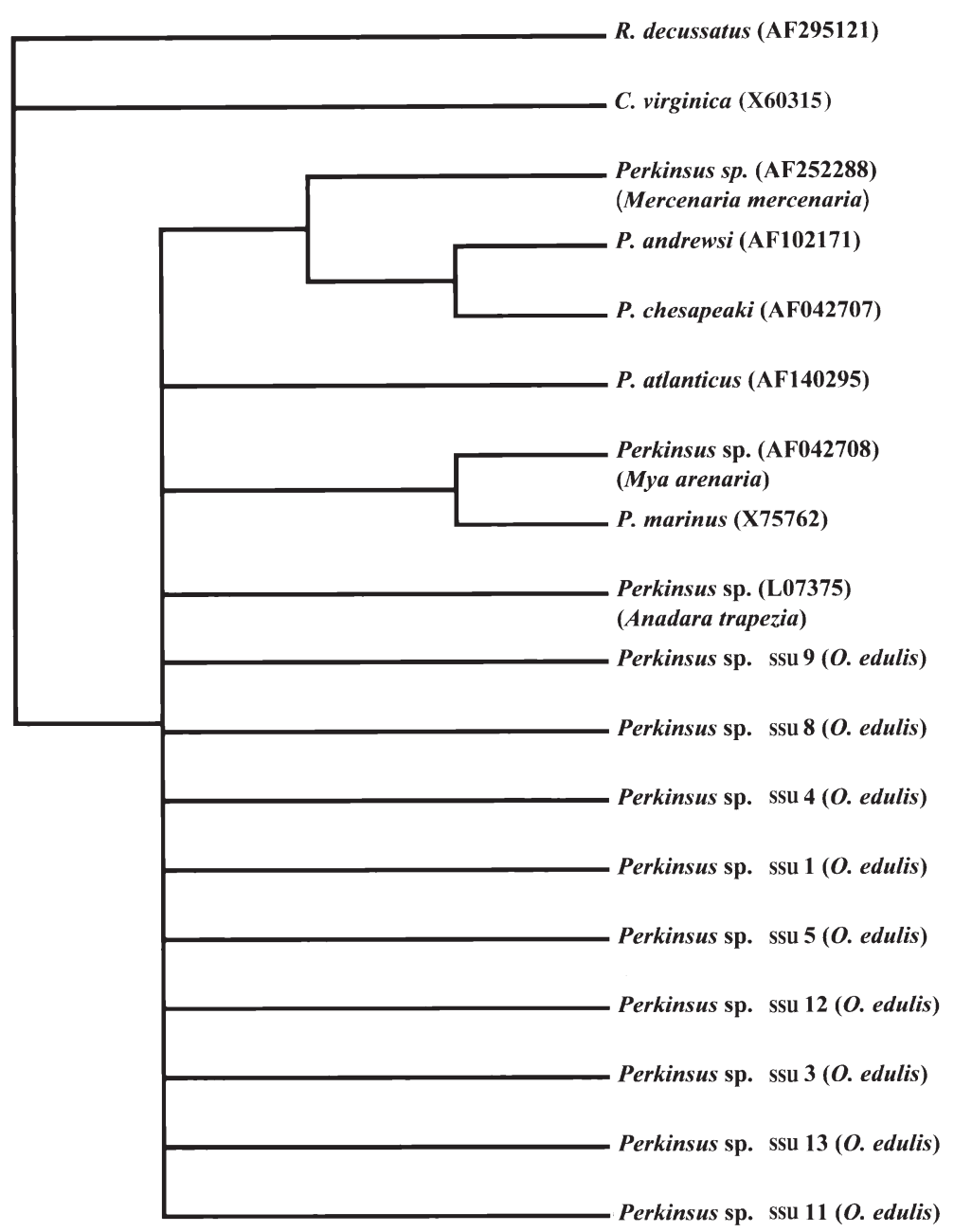

Fig. 18. Perkinsus spp. ssu rRNA gene sequences. Parsimony jackknife consensus tree found by analysis with 100 replicates of 100 random additions of the ssu gene sequences of ribosomal RNA complex of Perkinsus species and representative host spp. ( $R$. decussatus $=$ Ruditapes decussatus; $C$. virginica = Crassostrea virginica). Numbers on nodes indicate jackknife support values for groups where value was $>60$. $P$. mediterraneus sequences determined for this study are designated 'Perkinsus sp. ssuX $(O$. edulis)', where ' $\mathrm{X}$ ' indicates DNA clone number for the sequence. GenBank Accession Nos. and, where necessary, the host spp. for sequences designated as Perkinsus

spp., are listed in parentheses for all other sequences used in analysis

was significantly smaller than after the other 2 longer (14 and $21 \mathrm{~d}$ ) incubation periods, but mean prezoosporangium size did not reach $40 \mu \mathrm{m}$ during any incubation period. Mortality was $100 \%$ for each replicate at the longest incubation period.

\section{DISCUSSION}

A Perkinsus-like parasite has been detected in tissues of Ostrea edulis from the Balearic Islands, in the Mediterranean Sea. The morphology of the different stages of the parasite and of its zoosporulation stages resemble those of other Perkinsus species (Mackin et al. 1950, Lester \& Davis 1981, Azevedo 1989, Blackbourn et al. 1998, McLaughlin et al. 2000, Coss et al. 2001a). The parasitic cells in the oyster tissues increased in size after incubation in RFTM. Incubation of host tissues in RFTM is a widely used diagnostic technique for Perkinsus spp. (Ray 1966, Bushek et al. 1994, Rodríguez \& Navas 1995). One of the authors (A. G.) has used it as a routine technique to estimate the prevalence of this parasite in oysters at growing sites in the study area, and, using light microscopy, has observed the genus typical dark spheres that become visible after immersion of RFTM-incubated tissue in Lugol's solution. She found that up to $70 \%$ of the oysters were infected in autumn samples. Some morphological characters and the sequence of the analysed DNA regions of the European flat oyster parasite are, however, different from those of the species currently included in the genus Perkinsus.

Trophozoite morphology is of limited taxonomic value, because it can be influenced by the host (Goggin \& Lester 1995), the time of year (Ray \& Chandler 1955, Bushek et al. 1994) and nutrient availability (La Peyre et al. 1993, La Peyre \& Faisal 1996, Casas et al. 2002b).

Some differences have been reported in the morphological characters of the prezoosporangium/zoosporangium among Perkinsus spp., such as prezoosporangium size, ratio between discharge tube length and zoosporangial body diameter, and number of discharge tubes. The morphology of the prezoosporangium/zoosporangium of the European flat oyster parasite did not match with any group of

Table 1. Perkinsus spp. Mean size ( \pm SE) and viability of $P$. atlanticus prezoosporangia after incubation of Tapes decussatus-infected gills in RFTM for 7, 14 and $21 \mathrm{~d}$. Size of $P$. mediterraneus prezoosporangia included for comparison. nd: no data

\begin{tabular}{|c|c|c|c|}
\hline \multirow{2}{*}{$\begin{array}{l}\text { Incubation } \\
\text { (d) }\end{array}$} & \multicolumn{2}{|c|}{ P. atlanticus } & \multirow{2}{*}{$\begin{array}{l}\text { P. mediterraneus } \\
\text { Size }(\mu \mathrm{m})\end{array}$} \\
\hline & Viability \% & Size $(\mu \mathrm{m})$ & \\
\hline 7 & 82 & $35.2 \pm 0.85$ & $97.4 \pm 1.99$ \\
\hline 14 & 5 & $39.8 \pm 0.68$ & $167.1 \pm 8.09$ \\
\hline 21 & 0 & $39.4 \pm 1.37$ & nd \\
\hline
\end{tabular}




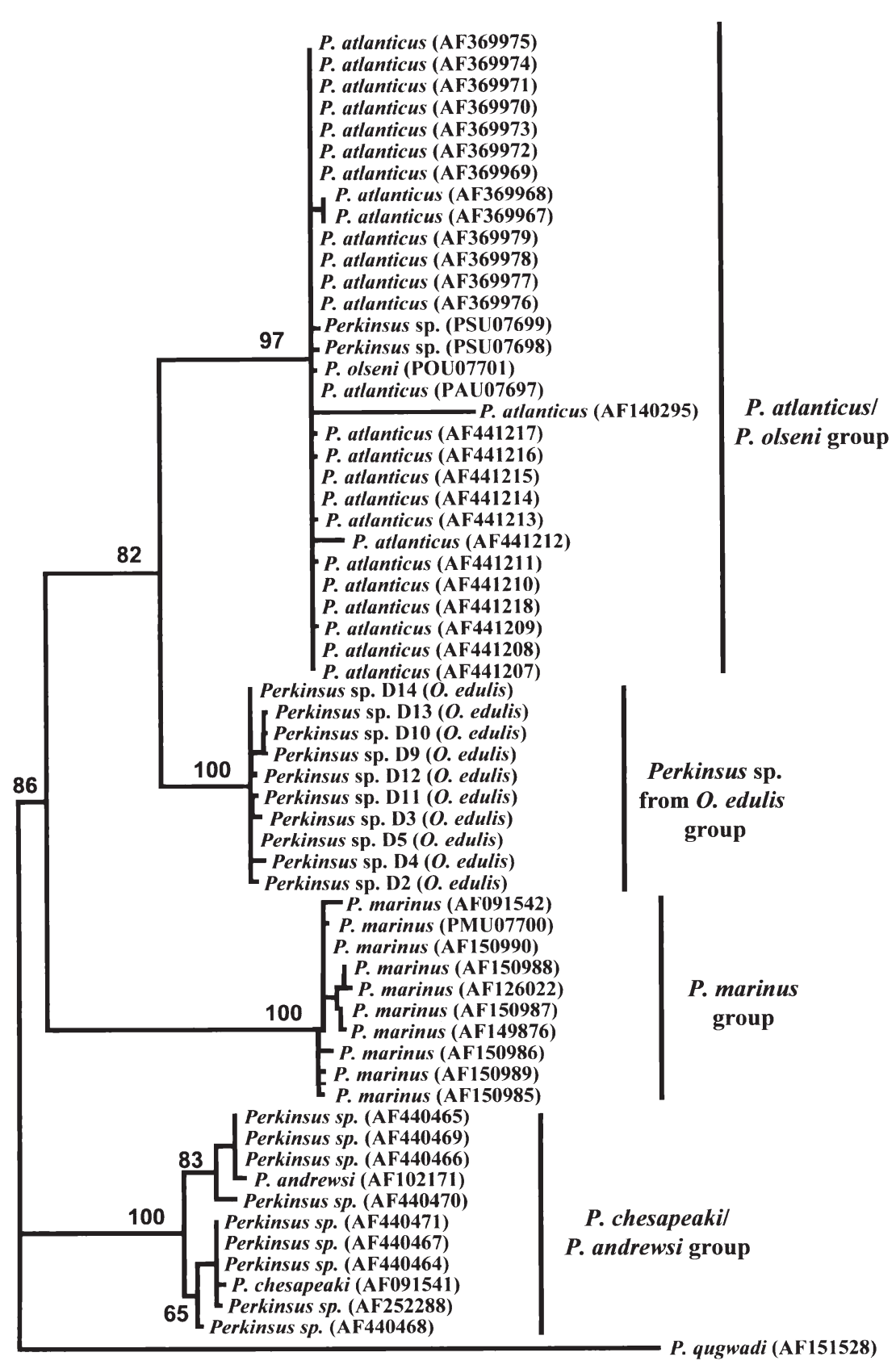

Fig. 19. Perkinsus spp. ITS-region DNA sequences. Parsimony jackknife consensus tree found by parsimony analysis with 100 replicates of 100 random additions of sequences for ITS region of ribosomal RNA complex of Perkinsus species. Numbers on nodes indicate jackknife support values for groups where value was $>60$. $P$. mediterraneus sequences determined for this study are designated 'Perkinsus sp. DX (O. edulis)', where ' $\mathrm{X}$ ' indicates DNA clone number for the sequence. GenBank Accession Nos. are listed in parentheses for all other sequences used in analysis

features described for other Perkinsus spp. The mean diameter of the prezoosporangium of the European flat oyster parasite $(97 \pm 1.99 \mu \mathrm{m}$; range $=62$ to $135 \mu \mathrm{m})$ after 1 wk incubation in RFTM was much greater than that of $P$. atlanticus (range $=30$ to $40 \mu \mathrm{m}$ ) (Azevedo
1989) and $P$. qugwadi $(12.6 \pm 1.18 \mu \mathrm{m})$ (Blackbourn et al. 1998), and slightly larger than that of $P$. olseni (mean = $74 \mu \mathrm{m}$; range $=56$ to $94 \mu \mathrm{m})$ (Lester \& Davis 1981), $P$. marinus ('often in the 30 to $80 \mu \mathrm{m}$ range') (Perkins 1996), $P$. chesapeaki $($ mean $=69.3 \pm 29.3 \mu \mathrm{m}$; range $=20$ to $135 \mu \mathrm{m}$ ) (McLaughlin et al. 2000) and $P$. andrewsi (mean $=67 \pm$ $12 \mu \mathrm{m})$ (Coss et al. 2001a). Ray (1952) reported individual $P$. marinus prezoosporangium diameters of 100 to $150 \mu \mathrm{m}$ after an RTM incubation of 1 wk or slightly longer, with values of up to $280 \mu \mathrm{m}$ being recorded. The maximum prezoosporangium diameter of the European flat oyster parasite incubated for 2 wk in RFTM was $317 \mu \mathrm{m}$. Although there are differences in prezoosporangium size between the European flat oyster parasite and other Perkinsus spp., the taxonomic value of these differences has not been established. Host and incubation conditions could affect prezoosporangium size. A study is necessary to evaluate the taxonomic value of this feature by comparing the various Perkinsus spp. under identical experimental conditions.

The discharge-tube length is onesixth the zoosporangial body diameter in the European flat oyster parasite, one-fifth in Perkinsus marinus, onequarter in P. olseni from Haliotis laevigata, one-third in Perkinsus spp. from Tridacna gigas, Anadara trapezia and Macoma balthica (Valiulis \& Mackin 1969, Goggin \& Lester 1995), and onethird (0.30) in P. atlanticus (Casas et al. 2002a), the former being the lowest described for any Perkinsus species.

Increasing the length of incubation in RFTM had different effects on the Perkinsus-like parasite of Ostrea edulis and on $P$. atlanticus, (the latter being the only species of the genus Perkinsus found in European waters thus far). Substantial cell-size increases, cell-wall thickening, and higher cell viability were seen in the former, while a significant but smaller cell-size increase and low or zero viability were observed in the latter.

Zoosporangia of the European flat oyster parasite had 1 or (less frequently) 2 discharge tubes. Two tubes 
have also been observed in Perkinsus marinus (Perkins \& Menzel 1966) and P. chesapeaki (McLaughlin et al. 2000). Zoosporangia with 2 discharge tubes occurred only after prolonged incubation ( $2 \mathrm{wk}$ ) in RFTM, when the European oyster-parasite cells had reached a large size.

At the ultrastructural level, the zoosporangium of the European flat oyster parasite had a very thick cell wall. This cell consisted of 2 layers, as in Perkinsus atlanticus (Azevedo et al. 1990) and P. chesapeaki (McLaughlin et al. 2000), whereas that of $P$. marinus has 3 layers (Perkins \& Menzel 1967). Lomosomes associated with the zoosporangial wall have been described in all Perkinsus species. (Perkins 1969, Azevedo et al. 1990, McLaughlin et al. 2000) except $P$. qugwadi and $P$. andrewsi (Blackbourn et al. 1998, Coss et al. 2001a), but these structures were not observed in the zoosporangium of the European flat oyster parasite. However, a glycocalyx-like structure was observed on the cellwall surface of the zoosporangium of the latter, a type of structure that has never been reported for Perkinsus spp.

The zoospore lengths of the Ostrea edulis parasite $(4.4 \pm 0.18 \mu \mathrm{m}$, range $=2.9$ to $5.8 \mu \mathrm{m})$ was within the range of Perkinsus spp.: 4 to $6 \mu \mathrm{m}$ in $P$. marinus (Perkins \& Menzel 1967), $4.5 \pm 0.6 \mu \mathrm{m}$ in P. atlanticus (Azevedo 1989), $4.5 \pm 1.0 \mu \mathrm{m}$ in P. qugwadi (Blackbourn et al. 1998), $4.4 \pm 0.6 \mu \mathrm{m}$ in $P$. andrewsi and $3.73 \pm 0.48 \mu \mathrm{m}$ in P. chesapeaki (McLaughlin et al. 2000). The fine structure of the zoospores of the $O$. edulis parasite also corresponded to that of Perkinsus spp. The angle forming the flagella at their insertion (which has received taxonomic attention: Perkins \& Menzel 1967, Azevedo 1989, Blackbourn et al. 1998, McLaughlin et al. 2000) could not be measured because of the lack of satisfactory images. An electrondense body in the basal body that has been described in all Perkinsus spp. (Perkins \& Menzel 1967, Azevedo 1989, McLaughlin et al. 2000, Coss et al. 2001a) except P. qugwadi (Blackbourn et al. 1998) was observed in the $O$. edulis parasite. Cortical alveoli were observed in the anterior cellular surface as in $P$. marinus (Perkins 1996), P. atlanticus (Azevedo 1989) and P. chesapeaki (McLaughlin et al. 2000), in contrast to P. andrewsi, in which they occur in the anterior region of the zoospore and occasionally in other regions of the cell (Coss et al. 2001a), and to P. qugwadi, in which they occur anywhere on the surface of the zoospore (Blackbourn et al. 1998).

Molecular phylogenetic analysis supported the morphological data, suggesting that the Perkinsus-like parasite from Ostrea edulis is a new undescribed Perkinsus species. ssu rRNA gene sequences of Perkinsus species show little interspecific variation, and the ssu sequences from the Ostrea edulis parasite confirm its genus designation as Perkinsus. The high degree of conservation among Perkinsus ssu sequences hampers individual species identifications using this gene. In addition, the results of the sequence analysis, which determined multiple ssu sequences from the Ostrea edulis parasite, indicate intraspecific variation within the ssu gene, which would hinder discrimination of species. In contrast, the ITS sequences were able to resolve most described Perkinsus species. However, $P$. olseni and $P$. atlanticus ITS sequences could not be resolved further, supporting the recently proposed synonymy of these 2 species (Murrell et al. 2002). In addition, $P$. chesapeaki and $P$. andrewsi ITS sequences, together with sequences from clonal cultures of Perkinsus sp. isolated from Mya arenaria and Tagelus plebeius, form a monophyletic clade, and a recent study has suggested that these 2 species may also be synonymous (Dungan et al. 2002). The 10 ITS region sequences obtained in our study suggest, however, that the Perkinsus sp. from $O$. edulis is closely related to, yet distinct from, $P$. atlanticus and $P$. olseni. Although we combined parasite zoosporangia and zoospores from 20 different host-individuals for the DNA analysis, all 10 ITS sequences grouped together, while none of these ITS sequences grouped with sequences from already described Perkinsus species, strongly suggesting that only 1 Perkinsus species was isolated from the infected $O$. edulis used in this study. Although our relatively small dataset of ITS sequences from the $O$. edulis parasite may have missed some intra-specific variation, there is a very large dataset of ITS sequences for $P$. olseni/atlanticus and none of those sequences overlapped with our new ITS sequences. Reciprocal monophyly of the clades based on the molecular data supports our claim that this is a new Perkinsus species.

Gross morphological and ultrastructural examination revealed a few differences between Perkinsus sp. from Ostrea edulis and the other Perkinsus spp., with the molecular study revealing that Perkinsus sp. from Ostrea edulis is different from $P$. marinus, $P$. olseni/atlanticus, P. chesapeaki/andrewsi, and P. qugwadi. Thus, we conclude that the parasite of Ostrea edulis is a new species of the genus Perkinsus, and propose to name it Perkinsus mediterraneus n. sp.

The response of the Ostrea edulis cellular defence system against the trophozoites involved haemocytic infiltration of affected tissue areas and phagocytosis of parasite cells. Parasite encapsulation by a few oyster haemocytes was observed less frequently. Similarly, the most evident defence mechanism of another ostreid mollusc, Crassostrea virginica, against Perkinsus marinus was phagocytosis, although attempts at encapsulation of trophozoites by oyster haemocytes were occasionally seen (Mackin 1951, La Peyre et al. 
1995, Anderson 1996). In contrast, the main cellular response of the gastropod Haliotis rubra against $P$. olseni (Goggin \& Lester 1995), the venerids Tapes decussatus and T. philippinarum against $P$. atlanticus (Montes et al. 1995, 1996), the pectinid Patinopecten yessoensis against Perkinsus qugwadi (Bower et al. 1998 ) and the myacid Mya arenaria against $P$. chesapeaki (McLaughlin \& Faisal 1998) was encapsulation of the parasite.

Description and morphological aspects of Perkinsus mediterraneus n. sp. from Casas, Grau, Reece, Apakupakul, Azevedo, Villalba, are as follows:

Trophozoites. Uninucleated cells, spherical to ovoid, $7.9 \pm 0.34 \mu \mathrm{m}$ in diameter. Most of trophozoite is occupied by large vacuole that displaces the nucleus to the periphery of the cell. Vacuole usually contains a vacuoplast. Trophozoites have signet-ring appearance characteristic of Perkinsus spp. Cell is surrounded by wall-like structure.

Prezoosporangia and zoosporangia. Large-sized cells, obtained after incubation in RFTM, spherical to ovoid in shape. Diameter of the prezoosporangia is positively correlated with period of incubation in RFTM. Diameter of prezoosporangia after $1 \mathrm{wk}$ in RFTM is $97.4 \pm 1.99 \mu \mathrm{m}$, after $2 \mathrm{wk}$ it is $167.1 \pm 8.09 \mu \mathrm{m}$. Prezoosporangia have thick wall with external structure that resembles a glycocalyx. Prezoosporangia incubated in seawater become zoosporangia whose cytoplasm divides by successive binary divisions to produce biflagellated zoospores. Zoosporangia possess 1 or 2 discharge tubes. Discharge tube length is onesixth of zoosporangial body diameter.

Zoospores. Uninucleate, biflagellated cells, ellipsoidal to ovoid in shape, $4.4 \pm 0.18 \mu \mathrm{m}$ in length. Nucleus is positioned in posterior part, and both flagella and the apical ribbon are situated in anterior region. Ribbon-associated vesicles, toxicysts and rhoptries extend from anterior to posterior areas of the cell. Cortical alveoli are present on anterior part of cellular surface.

Type host. Trophozoites in the European flat oyster Ostrea edulis (Mollusca: Bivalvia).

Type locality. Coastal area in proximity to Maó Port $\left(39^{\circ} 53^{\prime} 39^{\prime \prime} \mathrm{N}, 4^{\circ} 19^{\prime} 15^{\prime \prime} \mathrm{E}\right)$, Isle of Menorca, Balearic Islands, Spain.

Prevalence. Seasonal, with peak prevalence in late summer and autumn. Up to $70 \%$ infected oysters.

Material deposited. Stained slides of infected oyster Ostrea edulis sections have been deposited in the International Protozoan Type Slide Collection at the Smithsonian Institution, Washington, DC 20560 (No. USNM1005218) The ssurRNA gene and ITS region sequences accessible at GenBank (Accession Nos. for ssu rRNA gene sequences: AY486139, AY486140, AY486141, AY487831, AY487832, AY487833, AY517645, AY517646, AY517647. Acces- sion Nos. for ITS region sequences: AY487834 to AY487843).

Etymology. Specific epithet derives from geographical area where the parasite was found, the Mediterranean Sea.

Acknowledgements. E. Penas, M. I. Meléndez and L. Corral provided technical assistance, J. M. Valencia sampled the oysters. This work was partially supported by funds of the Secretaría Xeral de Investigación e Desenvolvemento Tecnolóxico da Xunta de Galicia, through the project PGIDTCIMA 99/10, and by funds of the Planes Nacionales JACUMAR 1999. S.M.C. was supported by a scholarship from the Consellería de Pesca e Asuntos Marítimos da Xunta de Galicia. This is VIMS contribution number 2579.

\section{LITERATURE CITED}

Altschul SF, Gish W, Miller W, Myers EW, Lipman DJ (1990) Basic local alignment search tool. J Mol Biol 215:403-410

Anderson RS (1996) Interactions of Perkinsus marinus with humoral factors and hemocytes of Crassostrea virginica. J Shellfish Res 15:127-134

Andrews JD, Hewatt WG (1957) Oyster mortality studies in Virginia. II. The fungus disease caused by Dermocystidium marinum in oysters of Chesapeake Bay. Ecol Monogr $27: 1-26$

Azevedo C (1989) Fine structure of Perkinsus atlanticus n. sp. (Apicomplexa, Perkinsea) parasite of the clam Ruditapes decussatus from Portugal. J Parasitol 75:627-635

Azevedo C, Corral L, Cachola R (1990) Fine structure of zoosporulation in Perkinsus atlanticus (Apicomplexa; Perkinsea). Parasitology 100:351-358

Berilli F, Ceschia G, Basilicata L, De Liberato C, Di Cave D, Mokhamer E, Orecchia P (1998) Monitoraggio parassitologico di Chamelea gallina (Mollusca, Bivalvia) in Adriatico. Parassitologia 40:2

Blackbourn J, Bower SM, Meyer GR (1998) Perkinsus qugwadi sp. nov. (incertae sedis), a pathogenic protozoan parasite of Japanese scallops, Patinopecten yessoensis, cultured in British Columbia, Canada. Can J Zool 76:942-953

Bower SM, Blackbourn J, Meyer GR (1998) Distribution, prevalence, and pathogenicity of the protozoan Perkinsus qugwadi in Japanese scallops, Patinopecten yessoensis, cultured in British Columbia, Canada. Can J Zool 76: 954-959

Burreson EM, Ragone Calvo LM (1996) Epizootiology of Perkinsus marinus disease of oysters in Chesapeake Bay, with emphasis on data since 1985. J Shellfish Res 15: 17-34.

Bushek D, Ford SE, Allen SK (1994) Evaluation of methods using Ray`s fluid thioglycollate medium for diagnosis of Perkinsus marinus infection in the eastern oyster, Crassostrea virginica. Annu Rev Fish Dis 4:201-217

Canestri-Trotti G, Baccarani EM, Paesanti F, Turolla E (1999) Infezioni parassitarie in mitili (Mytilus galloprovincialis) provenienti da Goro (Ferrara-Nord Adriatico-Italia). Boll Soc Ital Patol 26:40-48

Canestri-Trotti G, Baccarani EM, Paesanti F, Turolla E (2000a) Monitoring of infections by protozoa of the genera Nematopsis, Perkinsus and Porospora in the smooth venus clam Callista chione from the North-Western Adriatic Sea (Italy). Dis Aquat Org 42:157-161

Canestri-Trotti G, Baccarani EM, Paesanti F, Turolla E (2000b) 
Parasitological monitoring of Musculista senhousia (Mollusca: Bivalvia), invasive marine species, in the Sacca of Goro lagoon (Ferrara-Italy). $31^{\circ}$ Congresso SIBM, Sharm El Sheik, May 13-20, 2000, Dipartimento di Biologia Animale e Dell'Uomo, Universita'di Roma 'La Sapienza', p 80

Carlini DB, Graves JE (1999) Phylogenetic analysis of cytochrome $\mathrm{C}$ oxidase I sequences to determine higherlevel relationships within the coleoid cephalopods. Bull Mar Sci 64:57-66

Casas SM, Villalba A, Reece KS (2002a) Study of the perkinsosis of the carpet shell clam Tapes decussatus in Galicia (NW Spain). I. Identification of the etiological agent and in vitro modulation of zoosporulation by temperature and salinity. Dis Aquat Org 50:51-65

Casas SM, La Peyre JF, Reece KS, Azevedo C, Villalba A (2002b) Continuous in vitro culture of the carpet-shell clam Tapes decussatus protozoan parasite Perkinsus atlanticus. Dis Aquat Org 52:217-231

Ceschia G, Zentilin A, Giorgetti G (1991) Presenza di Perkinsus in vongole veraci (Ruditapes philippinarum) allevate nel Nord-Est Italia. Boll Soc It Patol Ittica 5:101-108

Choi KS, Park KI (1997) Report on the occurrence of Perkinsus sp. in the Manila clams, Ruditapes philippinarum in Korea. J Aquacult 10:227-237

Coss CA, Robledo JAF, Vasta GR (2001a) Fine structure of clonally propagated in vitro life stages of a Perkinsus sp. isolated from the Baltic clam Macoma balthica. J Eukaryot Microbiol 48:38-51

Coss CA, Robledo JAF, Ruiz GM, Vasta GR (2001b) Description of Perkinsus andrewsi n. sp. isolated from the Baltic clam (Macoma balthica) by characterization of the ribosomal RNA locus, and development of a species-specific PCR-based diagnostic assay. J Eukaryot Microbiol 48: $52-61$

da Ros L, Canzonier WJ (1985) Perkinsus, a protistan threat to bivalve culture in the Mediterranean basin. Bull Eur Assoc Fish Pathol 5:23-27

de la Herrán R, Garrido-Ramos MA, Navas JI, Ruiz-Rejón C, Ruiz-Rejón M (2000) Molecular characterization of the ribosomal RNA gene region of Perkinsus atlanticus: its use in phylogenetic analysis and as a target for a molecular diagnosis. Parasitology 120:345-353

Dungan CF, Hamilton RM, Hudson KL, McCollough CB, Reece KS (2002) Two epizootic diseases in Chesapeake Bay commercial clams, Mya arenaria and Tagelus plebeius. Dis Aquat Org 50:67-78

Flores BS, Siddall ME, Burreson EM (1996) Phylogeny of the Haplosporidia (Eukaryota: Alveolata) based on small subunit ribosomal RNA gene sequence. J Parasitol 82: 616-623

Fong D, Rodríguez R, Koo K, Sun J, Sogin ML, Bushek D, Littlewood DTJ, Ford SE (1993) Small subunit ribosomal RNA gene sequence of the oyster parasite Perkinsus marinus. Mol Mar Biol Biotechnol 2:346-350

Ford SE (1996) Range extension by the oyster parasite Perkinsus marinus into the Northeastern United States: response to climate change? J Shellfish Res 15:45-56

Goggin CL (1992) Occurrence of parasites of the genus Perkinsus in France. Bull Eur Assoc Fish Pathol 12: 174-176

Goggin CL (1994) Variation in the two internal transcribed spacers and 5.8S ribosomal RNA from five isolates of the marine parasite Perkinsus (Protista, Apicomplexa). Mol Biochem Parasitol 65:179-182

Goggin CL, Barker SC (1993) Phylogenetic position of the genus Perkinsus (Protista, Apicomplexa) based on small subunit ribosomal RNA. Mol Biochem Parasitol 60:65-70
Goggin CL, Lester RJG (1995) Perkinsus, a protistan parasite of abalone in Australia: a review. Mar Freshw Res 46: $639-646$

Kotob SI, McLaughlin SM, Van Berkum P, Faisal M (1999) Characterization of two Perkinsus spp. from the softshell clam, Mya arenaria using the small subunit ribosomal RNA gene. J Eukaryot Microbiol 46:439-444

La Peyre JF, Faisal M (1996) Optimal culture conditions for the propagation of the oyster pathogen Perkinsus marinus (Apicomplexa) in protein deficient medium. Parasite 3 : 147-153

La Peyre JF, Faisal M, Burreson EM (1993) In vitro propagation of the protozoan Perkinsus marinus, a pathogen of the eastern oyster, Crassostrea virginica. J Eukaryot Microbiol 40:304-310

La Peyre JF, Chu FL, Vogelbein W (1995) In vitro interaction of Perkinsus marinus merozoites with eastern and Pacific oyster hemocytes. Dev Comp Immunol 19:291-304

Lester RJG, Davis GHG (1981) A new Perkinsus species (Apicomplexa, Perkinsea) from the abalone Haliotis ruber. J Invertebr Pathol 37:181-187

Littlewood DT, Ford SE, Fong D (1991) Small subunit rRNA gene sequence of Crassostrea virginica (Gmelin) and a comparison with similar sequences from other bivalve molluscs. Nucleic Acids Res 19:6048

Mackin JG (1951) Histopathology of infection of Crassostrea virginica (Gmelin) by Dermocystidium marinus Mackin, Owen, and Collier. Bull Mar Sci Gulf Caribb 1:73-87

Mackin JG, Hopkins SH (1962) Studies on oyster mortality in relation to natural environment and to oil fields in Louisiana. Publ Inst Mar Sci Univ Tex 7:1-131

Mackin JG, Owen HM, Collier A (1950) Preliminary note on the occurrence of a new protistan parasite, Dermocystidium marinum n. sp. in Crassostrea virginica (Gmelin). Science 111:328-329

McLaughlin SM, Faisal M (1998) Histopathological alterations associated with Perkinsus spp. infection in the softshell clam Mya arenaria. Parasite 5:263-271

McLaughlin SM, Tall BD, Shaheen A, Elsayed EE, Faisal M (2000) Zoosporulation of a new Perkinsus species isolated from the gills of the softshell clam Mya arenaria. Parasite $7: 115-122$

Medlin L, Elwood HJ, Stickel S, Sogin ML (1988) The characterization of enzymatically amplified eukaryotic 16S-like rRNA-coding proteins. Gene 71:491-499

Montes JF, Durfort M, García-Valero J (1995) Cellular defence mechanism of the clam Tapes semidecussatus against infection by the protozoan Perkinsus sp. Cell Tissue Res 279:529-538

Montes JF, Durfort M, García-Valero J (1996) When the venerid clam Tapes decussatus is parasitized by the protozoan Perkinsus sp. it synthesizes a defensive polypeptide that is closely related to p225. Dis Aquat Org 26:149-157

Murrell A, Kleeman SN, Barker SC, Lester RJG (2002) Synonymy of Perkinsus olseni Lester \& Davis, 1981 and Perkinsus atlanticus Azevedo, 1989 and an update on the phylogenetic position of the genus Perkinsus. Bull Eur Assoc Fish Pathol 22:258-265

Norén F, Moestrup O, Rehnstam-Holm AS (1999) Parvilucifera infectans Norén et Moestrup gen. et sp. nov. (perkinsozoa phylum nov.): a parasitic flagellate capable of killing toxic microalgae. Eur J Protistol 35:233-254

Park KI, Choi KS (2001) Spatial distribution of the protozoan parasite Perkinsus sp. found in the Manila clams, Ruditapes philippinarum, in Korea. Aquaculture 203:9-22

Perkins FO (1969) Ultrastructure of vegetative stages in Labyrinthomyxa marina (= Dermocystidum marinum), a 
commercially significant oyster pathogen. J Invertebr Pathol 13:199-222

Perkins FO (1996) The structure of Perkinsus marinus (Mackin, Owen \& Collier, 1950) Levine, 1978 with comments on taxonomy and phylogeny of Perkinsus spp. J Shellfish Res 15:67-88

Perkins FO, Menzel RW (1966) Morphological and cultural studies of a motile stage in the life cycle of Dermocystidium marinum. Proc Natl Shellfish Assoc 56:23-30

Perkins FO, Menzel RW (1967) Ultrastructure of sporulation in the oyster pathogen Dermocystidium marinum. J Invertebr Pathol 9:205-229

Ray SM (1952) A culture technique for the diagnosis of infections with Dermocystidium marinum Mackin, Owen, and Collier in oysters. Science 116:360-361

Ray SM (1966) A review of the culture method for detecting Dermocystidium marinum, with suggested modifications and precautions. Proc Natl Shellfish Assoc 54:55-69

Ray SM, Chandler AC (1955) Dermocystidium marinum, a parasite of oysters. Exp Parasitol 4:172-200

Reece KS, Siddall ME, Burreson EM, Graves JE (1997) Phylogenetic analysis of Perkinsus based on actin gene sequences. J Parasitol 83:417-423

Robledo JAF, Coss CA, Vasta GR (2000) Characterization of the ribosomal RNA locus of Perkinsus atlanticus and development of a polymerase chain reaction-based diagnostic assay. J Parasitol 86:972-978

Rodríguez F, Navas JI (1995) A comparison of gill and hemolymph assays for the thioglycollate diagnosis of Perkinsus atlanticus (Apicomplexa, Perkinsea) in clams, Ruditapes decussatus (L.) and Ruditapes philippinarum (Adams et Reeve). Aquaculture 132:145-152

Sagristà E, Durfort M, Azevedo C (1996) Ultrastructural study of the parasite, Perkinsus atlanticus (Apicomplexa), on the clam Ruditapes philippinarum, in the Mediterranean. Sci

Editorial responsibility: Albert Sparks,

Seattle, Washington, USA
Mar 60:283-288

Santmartí MM, García-Valero J, Montes JF, Pech A, Durfort M (1995) Seguimiento del protozoo Perkinsus sp., en las poblaciones de Tapes decussatus y Tapes semidecussatus del delta del Ebro In: Castelló F, Calderer A (eds) Actas del V Congreso Nacional de Acuicultura, May 10-13, 1995, S. Carlos de la Rápita. Spain, Universidad de Barcelona, p 260-265

Seutin G, White BN, Boag PT (1991) Preservation of avian blood and tissue samples for DNA analyses. Can J Zool 69: $82-90$

Shaw BL, Battle HI (1957) The gross and microscopic anatomy of digestive tract of the oyster Crassostrea virginica (Gmelin). Can J Zool 35:325-347

Siddall ME, Stokes NA, Burreson EM (1995) Molecular phylogenetic evidence that the phylum Haploporidia has an alveolate ancestry. Mol Biol Evol 12:573-581

Siddall ME, Reece KS, Graves JE, Burreson EM (1997) 'Total evidence' refutes the inclusion of Perkinsus species in the phylum Apicomplexa. Parasitology 115: $165-176$

Soniat TM (1996) Epizootiology of Perkinsus marinus disease of eastern oysters in the Gulf of Mexico. J Shellfish Res 15: 35-44

Swofford DL (2001) PAUP*. Phylogenetic analysis using parsimony ( ${ }^{*}$ and other methods), Version 4. Sinauer Associates, Sunderland, MA

Thompson JD, Higgins DG, Gibson TJ (1994) Improving the sensitivity of progressive multiple sequence alignment through sequence weighting, positions-specific gap penalties and weight matrix choice. Nucleic Acids Res 22: 4673-4680

Valiulis GA, Mackin JG (1969) Formation of sporangia and zoospores by Labyrinthomyxa sp. parasitic in the clam Macoma balthica. J Invertebr Pathol 14:268-270

Submitted: March 19, 2003; Accepted: October 10, 2003

Proofs received from author(s): January 19, 2004 